\title{
TRADE IMPLICATIONS OF GRID EMISSION FACTORS UNDER CLIMATE CHANGE AND THE GREEN ECONOMY: COMPARATIVE STUDY OF AfRICAN AND ASIAN CONTINENTS
}

\author{
Chipo Mukonza* \\ University of South Africa \\ mukonc@unisa.ac.za
}

Received: May 2015

\author{
Godwell Nhamo" \\ University of South Africa \\ nhamog@unisa.ac.za \\ Accepted: October 2015
}

\begin{abstract}
Trade, climate change, and the green economy are aspects that converge on the carbon footprint of organisations, products and countries. The carbon footprint is in turn linked directly to the grid emission factors (GEFs) of a country or sub-regions within that country. In an epoch where global citizens are increasingly aware of the adverse impacts of high greenhouse gas emissions leading to global warming, low carbon footprints are likely to attract greater trade opportunities. African and Asian countries have embraced the green economy to address economic development, environmental management and social equity challenges. The advent of the green economy means that trade is likely to result in the more efficient allocation of natural resources, as well as improved access to green goods, services and technologies. Through the examination and analysis of publicly available and accessible data and documents, this article seeks to compare the 'green' trade competitiveness of Asian and African economies as measured through carbon footprints. The results of the study show that Africa is relatively cleaner than Asia. Therefore, ceteris paribus, if GEFs are used to determine trading partners, Africa stands a better chance. The research findings can be used to make informed strategic trade decision in favour of environmental sustainability.
\end{abstract}

Keywords

Green economy, climate change, grid emission factors, trade, Africa, Asia

*Dr C Mukonza is a Post-Doctoral Fellow under the Exxaro Chair: Business and Climate Change at the Institute for Corporate Citizenship, University of South Africa, South Africa.

\#Prof G Nhamo is Chief Researcher and Exxaro Chair in Business and Climate Change at the Institute for Corporate Citizenship, University of South Africa, South Africa. 


\section{INTRODUCTION}

Climate change has the potential to damage seriously ecosystems and our natural environment, thereby negatively impacting the global economy. In recent times, it has been recognised that climate change represents the world's most pressing long-term threat to future prosperity and security (Zhang, 2009:1). Since greenhouse gas emissions (GHGs) are virtually embodied in all products produced and traded in every conceivable economic sector, actually addressing climate change will require a fundamental transformation of economies. This means changing the ways energy is produced and used. Zhang (2009:1) also argues that the way energy is produced has a bearing on world trade, as it will affect the costs of products and competitive position in the global marketplace.

A report by the South Center Trade - SCT (2009:5) posits that global trade is informed by both the international rules and disciplines under the World Trade Organisation (WTO). The SCT report argues that climate change and its impacts are increasingly shaping the environment under which economic activity takes place in both developing and developed countries. Be that as it may, conflicts have arisen in the implementation of international trade regulations, especially on issues concerning GHG emissions embodied in all products marketed in every conceivable economic sector. To reduce potential conflict between trade and the emerging global environmental regime to combat climate change, the WTO could prioritise issues currently on the agenda to harness and promote broader global environmental objectives (World Bank, 2007:47). The WTO negotiations on environmental goods and services could be used as a vehicle for broadening trade in cleaner technology options. Consequently helping developing countries reduce their GHG emissions and mitigate climate change, through reduced carbon footprints (World Bank, 2007:47).

The WTO agreement recognises that trade should be conducted while allowing for the optimal use of the world resources by way of the objective of sustainable development. This way, trade must seek both to provide and remove pressure on the environment and enhance the means of doing so. It is imperative to have these regulations at the highest level in order to ensure efficiency in the use of resources. The intention is to maximise the gains from the comparative advantage of nations through trade while at the same time ensuring that economic development is sustainable.

The relationship between sustainable development, climate change and trade has the potential to facilitate the transition to a green economy by fostering the exchange of environmentally friendly goods and services. The aim is to increase resource efficiency, generate economic opportunities and employment, and contribute towards poverty eradication (UNEP, ITC and ICTSD, 2012:1). The impact of trade on a green economy transition depends in large part on how trade policies are designed and applied. Also vital is whether adequate national and institutional conditions (e.g. institutional and regulatory regimes) exist to cope with the impact of liberalisation. Resnick et al. (2012:8) suggest that measures related to the green growth agenda could include, for instance, the imposition of standards and regulations that would increase the costs of goods exported by developing countries. Border carbon taxes could also be implemented in order to compensate for the different climate change mitigation commitments in advanced and developing countries. A number of countries have voiced concerns regarding green economy policy measures, such as subsidies, standards, intellectual property rights and border measures, indicating that they may be used to restrict international trade (UNEP, ITC and ICTSD, 2012:1).

This article focuses on international trade and countries' specific carbon footprints, which were drawn and computed from using a particular country's Grid Emission Factors (GEFs) as a 
parameter. This is examined through the carbon footprints lens expressed as the GEFs of selected Asian and African countries. It is assumed that trading in a green economy transition poses a risk to carbon-intensive producers, especially countries that continually seek access to lucrative $\varepsilon U$ and $0 \varepsilon C D$ markets. The research findings, therefore, have the potential to inform energy policymaking and implementation in the case study continents of Asia and Africa. The findings are also of value globally as governments seek to achieve the triple mandate of environmental stewardship, economic development and the improvement of human well-being.

The remainder of this article comprises the following main sections: the literature review is dealt with in the next section; a discussion of the research design follows in the third section; the fourth section presents the findings and the analysis of the results; while the fifth section presents the conclusion and some policy recommendations.

\section{LITERATURE REVIEW}

UNEP (2011:14) defined a green economy (inclusive of green growth) as "one that results in improved human well-being and social equity while significantly reducing environmental risks and ecological scarcities". Therefore, a green economy implies that countries need to adopt low carbon options, greater resource efficiencies and social inclusion. OECD (2013:9) describes green growth as fostering economic growth and development while ensuring that natural assets continue to provide the resources and environmental services on which our well-being relies. To do this, it must catalyse investment and innovation that will underpin sustained growth and give rise to new economic opportunities. Developing countries have been known to grow and clean later. However, with rapid economic growth, increased pollution, global warming and the depletion of natural resources, it has become vital to preserve future growth. Projections indicate that between 2020 and 2030, developing country emissions of carbon from energy use will exceed those of developed countries (International Energy Agency - IEA, 2014a:5).

Related to climate change is the notion of global warming that results from GHG emissions. Global warming is linked to radiation, which is a direct measure of the imbalance between energy flowing into the earth's atmosphere from the sun's energy being reflected and radiated back out into space. Given that there is an enhanced thin layer of GHG accumulation in the atmosphere, less heat is radiated back from the earth's surface, causing the earth to heat up via the global warming phenomenon. Although some GHGs are present in the atmosphere, the largest share is carbon dioxide (Intergovernmental Panel on Climate Change - IPPC, 2014:8).

According to the IPCC, in 2012 an estimated $67 \%$ of GHG emissions were subject to national legislation and/or strategies, while $45 \%$ were in 2007 (IPCC, 2014:9). However, determining the impact of this legislation and these strategies is still in its infancy. The Fifth Assessment Report (IPCC, 2014:11) postulates that to avoid temperatures rising more than the critical 2 degrees Celsius, GHG emissions need to be cut by between 30 and $60 \%$ of their 2010 levels by 2050 (IPCC, 2014:11). The report argues that GHG emissions are still on the rise, with the energy supply sector accounting for the largest proportion of GHG emissions. Accordingly, the report recommends that countries should consider increasing their use of low-carbon energy sources like solar, the wind, and nuclear energy in the generation of electricity.

Despite its ubiquitous appearance, there is no universal agreement regarding the definition of the term carbon footprint, and there is still some confusion as to how it is measured and what unit is to be used (Weidman \& Minx, 2008:4). Perhaps the most widely used definition is that provided by 
the Carbon Trust: 'a technique for identifying and measuring the individual greenhouse gas emissions from each activity within a supply chain process step and the framework for attributing these to each output product (referred to as the product's "carbon footprint")' (Carbon Trust 2007:4). Weidman and Minx (2008:6) emphasised that carbon footprint should include actions of individuals, populations, governments, companies, organisations, processes, industry sectors, etc. The term also takes in the production and consumption of all products, goods and services. The notion of the carbon footprint takes into account all direct (on-site, internal) and indirect emissions (off-site, external, embodied, upstream, and downstream). A carbon footprint is therefore reduced to a single digit that consumers can use to determine their choice of organisation to do business with and which products to consume (Nhamo, 2014a). Hertwich and Peters (2009: 6414) pointed out that the concept of a carbon footprint captures the interest of businesses, consumers and policymakers alike. Investors watch the carbon footprint of their portfolios as an indicator of investment risk. For their part, purchasing managers are curious about the carbon footprint of their supply chains, and consumers are increasingly offered carbonlabelled products. At the centre of carbon footprint computations are the GEFs of countries.

Climate change mitigation focuses on the reduction of footprints by employing less $\mathrm{GHG}$-emitting ways of producing, delivering, using and disposing of goods and services (Department of Economic and Social Affairs - DESA, 2013:32). Consequently, firms and countries are actively seeking methods to reduce the carbon intensity of their tradable products in order to attract trade in the green economies of the $21^{\text {st }}$ century. Part of these efforts has been the quest to measure accurately the GHG (often interchanged with carbon) emissions 'content' of various goods and services. A common measure of carbon content is the source of energy used to produce a good or service expressed as the GEF.

Blodgett (2013:3) states that GEFs are a measure factor of how dirty the power plants generating the electricity are, and they are is measured in tonnes of carbon dioxide equivalent per megawatthr produced ( $\mathrm{tCO} / \mathrm{MWh}$ ). GEFs are calculated based on the amount and type of fuel used per plant as well as the amount of electricity generated. High GEFs imply that electricity being produced by a country is dirty and will result in a high carbon footprint. On the other hand, low GEFs indicate that a country is employing cleaner methods of generating electricity, resulting in a low carbon footprint (which is likely to attract trade).

GEFs can also be used in conjunction with various Kyoto Protocol clean development mechanism (CDM) methodologies to calculate carbon credits (CDM Watch, 2014:3). Carbon credits are an essential unit in the carbon market. For many host countries, these GEFs are published by the Designated National Authority (DNA). The DNAs are responsible for approving CDM projects. According to the Southern African Power Pool - SAPP (2011:2) average emissions from the electricity generated by Southern African power plant stands at 1.0136 tonnes of carbon dioxide equivalent per MWhr. The SAPP (2011:3) maintains that the GEFs assume a linear relationship between the intensity of the activity and the emission resulting from the activities.

Some scholars are beginning to contest the use of GEFs. Spalding-Fecher (2011:8) states that the GEFs tool only applies to supply projects, not demand-side projects, and so do not consider emission and distribution losses between generation and end user. Blodgett (2013:3) posits that another challenge with the GEFs as a tool to determine the carbon footprints of countries is that gathering data is difficult, unreliable and complicated. To highlight how complex the tool is, other countries have received outside technical assistance to help them calculate their carbon footprints. The Australian government, for instance, assisted in calculating the GEFs of Ethiopia, Uganda and Rwanda. The Carbon Market Watch (2014:8) conducted a study to assess the 
reliability of the GEFs of 20 different countries. Their findings revealed that most of the 20 countries that had published GEFs did not follow the United Nations Framework Convention on Climate Change (UNFCCC) rules on how to establish such GEFs. The study also indicated that the documents used provide so little information that it is impossible to determine the quality of the GEFs. Whatever the methodologies and their defects thereof, GEFs are being applied in calculating the carbon footprints of organisations, products and countries. It, therefore, remains a useful tool in trade, climate change and the green economy nexus.

Transitioning to the green economy presents risks and opportunities both at national and firm level by affecting the country's trade and economic competitiveness. Countries and companies have become increasingly concerned about managing their carbon intensity in a quest to both remain and achieve global competitiveness. Cosbey (2008:1) argues that goods can be defined as environmentally friendly by judging them by at least three criteria:

- Method of production: a good could be considered low-carbon because of the low amount of carbon emitted during its production process. This definition, however, gets into the difficulties associated with processes and production method (PPM) -based discrimination.

- Its end-use as consumer goods: a hybrid car (driven by both an efficient internal combustion engine) and electric car might be considered low-carbon, since they emit fewer GHGs in use than do other conventional internal combustion engine cars. This, however, is a relative judgment, and would need to be adjusted over time - something the WTO would find difficult to do.

- Its end-use as intermediate goods: a windmill turbine might be considered low-carbon in that it is destined to contribute to energy generation in a manner that emits fewer GHGs than other conventional methods like coal- or liquid fossil fuel-powered plants. This sort of narrow definition would result in a list of goods in which, with only a few exceptions, developed countries have the overwhelming comparative advantage. However, this picture is rapidly changing with the entry into the renewable energy space by emerging economies like China, Brazil, India, Mexico and South Africa.

Technically, in a green economy world it becomes imperative to take into account the lifecycle of a good or service (UNEP, 2010:21). One would want to know how much GHG was emitted in the production process or offering of a particular service from cradle to grave and/or cradle compared to a baseline or reference case scenario. This would provide a basis to justify the use of particular trade partners. However, Cosbey (2008:6) notes that it is practically impossible to do a lifecycle analysis of every single good produced and service rendered by countries. This is because of the complexities associated with generating the data, its storage, retrieval and reliability. Various legislative, strategies and political fora have proposed the use of border carbon adjustments (BCAs) as a measure to address competitive concerns and carbon leakage.

De Mello (2012:4) introduced an interesting dimension when he suggested that whether a country is pursuing a 'green growth' development strategy depends first on its product mix and the production processes it uses (energy from fossil fuel or renewables). De Mello (2012:4) further states that production activities distinguish between tradable environment-related products and other products. The assumption is that tradable environment-related goods and services depend on whether their production helps manage the environment better (Goods for Environmental Management - GEMs, such as pumps for air pollution control) or if they are environmentally preferable products - EPPs, such as solar panels). For both GEMs and EPPs, reducing barriers to trade for these goods (or subsidising the production of clean energy) is seen as good for the 
environment. The distinction between these goods all rests on the GEFs of a given country, leading to the calculation of carbon footprints.

Relating to the theory of comparative advantage, trade between the developed countries of the northern hemisphere and the developing countries of the southern hemisphere has given rise to traditional gains from trade between countries with different factor endowments. Developing countries are said to be rich in natural resources and will export the services of these factors in exchange for the services of human and physical capital. However, given the exhaustibility or slow rate of renewal of natural resources, the traditional gains from trade can be overshadowed by the depletion of these resources in the exporting country due to trade-related over-exploitation, resulting in tensions between developed and developing countries.

There are a numbers of factors that have an impact on the competitiveness of countries in trade such as distance, geographic concentration of products and having the relevant carbon level standards. European countries and America have introduced labelling requirement energyefficiency standards that act as technical barriers to imports into other countries. The reason for these measures is to force reductions in carbon emissions and ultimately carbon footprints. Hufaure and Kim (2009:7) highlighted that the United States has drafted legislation that is buttressed by border adjustment mechanisms that would likely discriminate between domestic and foreign producers and among different foreign producers.

Numerous studies have also analysed the potential risks associated with the green economy transition process. Among the key risks noted are technological risks, and of concern to this article, the trade protectionism risk disguised as environmental concern. Despite these risks, there are a number of existing and future trade opportunities in a green growth era. Export markets for green and sustainable food, products, services, energy and tourism are expected to grow rapidly due to the changing consumer preferences as the world becomes more environmentally conscious (de Mello, 2012). Also, individuals are learning more about carbon footprints and how they can reduce them. As consumer demand for green goods and services increases, so will the incentives for firms to produce them and adopt more efficient and sustainable manufacturing methods that lead to reduced carbon footprints in the process.

\section{METHODOLOGY}

The authors used relevant information and data that was available in the public domain on the UNFCCC, IEA and Econometrica websites. The article also analysed reports of GEFs published by the DNAs of selected countries. Components of meta-analysis were used to analyse data. Timulak (2009:591) posits that meta-analysis is an attempt to conduct a rigorous secondary qualitative analysis of primary qualitative findings. The purpose of carrying out meta-analysis is to offer a more comprehensive description of a phenomenon. The focus and object of this article were to analyse the GEFs of African and Asian countries and how these could impact on trade under climate change and green economy transition. Africa and Asia were purposively selected, as they are the main contenders for European markets. In addition, Africa monitors closely the developments from Asia, where global economic giants have emerged, including China, India, Japan, South Korea and Malaysia.

Econometrica (2011:1) states that a distinction can be made between the GEFs for electricitygenerated transmission and distribution losses and consumption. Econometrica (2011) states that the calculated GEFs are for emissions per kWh of electricity generated within a country (i.e. 
total emissions divided by the total amount of electricity generated within a country). After a thorough examination of available data sets that had been collected, the researchers settled for the GEFs of electricity/heat emission factors. These data sets had been calculated by the IEA (2011b), while Econometrica (2011:4-7) calculated grids for electricity only. Saunders et al. (2007:199) posit that using secondary data within organisations may have the advantage that it provides an unobtrusive measure. Subsequently more time and effort is spent in analysing and interpreting data. The authors were able to benefit greatly from this.

All the countries from the two continents of Africa and Asia had equal chances of being sampled. However, the final inclusion or exclusion criteria depended on the availability of long-term data on GEFs. To this end, countries whose GEFs were available from 2006 to 2011 were those finally included in the sample. The final GEFs applied in the analysis were an average of the years of available data.

\section{PRESENTATION OF DATA AND DISCUSSION OF FINDINGS}

Concern is growing about the compatibility of climate change regimes with international trade rules, as national and international policies are being developed to mitigate the devastating impacts of climate change. A desirable future is one in which green economy transition is seen as a means of attaining sustainable development, poverty eradication and job creation (Nhamo, $2014 \mathrm{~b}: 21$ ). To attain this kind of future, measures to curtail carbon leakage are needed, especially in an era in which countries implement asymmetric climate policies. The article investigated the GEFs of African and Asian countries as these relate to trade under global climate change and green economy transition regimes. FIGURE 1 shows the GEFs of African countries.

The results from African countries show that South Africa and Botswana have very high GEFs. South Africa has an average GEF of 0.9 tonnes of carbon dioxide equivalent per MWh. The reason for this is that coal dominates the economy's electricity sector. Stern (2006:253) suggests that South Africa's intensive exports are likely to face growing challenges to competitiveness. In fact, South Africa has already been forced to start exporting its wine in bulk containers to reduce the product's carbon footprint resulting from this very high GEF (Vickers, 2013:13). What this implies is that failure to address the demand by consumers in the $\varepsilon U$ to export in bulk containers could have resulted in lost trade. Although the GEF for Kenya is not very high, contestation regarding the horticulture freight carbon footprint led to a huge controversy in 2006/7 when fresh flowers were dumped at airports. The primary concern was that the flowers had such a large carbon footprint that the $\varepsilon U$ and other carbon-sensitive trade destinations refused to let these flowers in (Muuru, 2009:6). The whole saga became known as the food miles debate and the horticultural sector in Kenya. The concept of food miles articulates the environmental impact of transporting food. The further food travels, the more energy is consumed in transportation. The term food miles was devised as a way of indicating to consumers the carbon footprint of food transported by air. The two case studies highlight an emerging carbon battle between Africa and its key trade partners. Nhamo (2014a:2) also pointed out that carbon wars in the civil aviation and maritime sectors are raging, with the European Union lobbying vigorously to include the two sectors in its carbon trading system. 


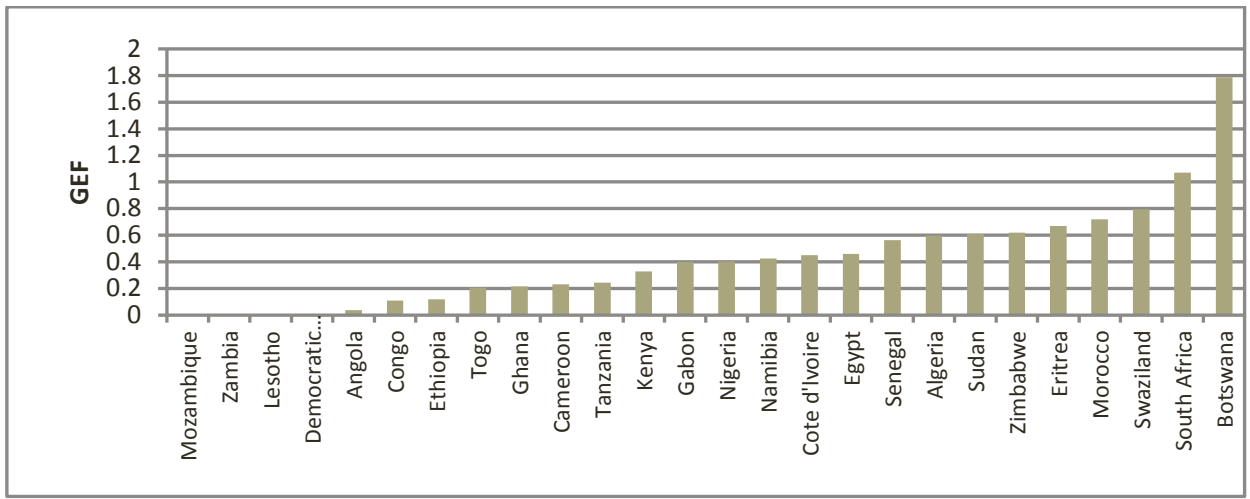

FIGURE 1: Average Grid emission factors of African countries (2008)

\section{Source: $\quad$ Constructed by the authors from data extracted from Econometrica (2011:4-7)}

From the results it has emerged that Botswana has the highest GEF. Botswana mainly uses coal in generating its electricity. The IEA (2010:57) states that the value of electricity production from coal sources in Botswana was $457,000,000 \mathrm{kWh}$ as of 2010 . The GEF might even go higher given the recent investments in more coal-fired power plants in the country by Canadian companies (Grynberg, 2012:6). The Canadian company CIC Energy has invested in a 200MW coal-fired plant in Botswana and plans to develop a $300 \mathrm{MW}$ coal-fired plant in the Mmamabula coal field (Reuters, 27 May 2012). Among the countries with very low GEFs are Mozambique, Zambia, Lesotho, Ethiopia, $\mathrm{DRC}$, Congo and Angola. All these countries rely on extensive hydroelectric power resources that indeed far exceed their needs (IEA, 2011:48).

Although Nigeria has low a GEF, this is not an accurate reflection of its demand. The country has one of the lowest net electricity generation per capita rates in the world (Nigeria Planning Country First Nuclear Plant). Electricity generation falls short of demand, resulting in load shedding, blackouts, and reliance on private generators. Africa and in particular Southern Africa has abundant energy sources such as coal, hydro, solar and wind, many of which are yet to be developed (Reuters, 27 May 2012). Besides South Africa and Botswana, which have high GEFs, 16 out of the 25 selected African countries fall within the range of 0.01-0.5 on the GEF scale. The results therefore mean that the countries are cleaner as far as their production of electricity is concerned. Cosbey and Wooders (2010:6) hint that ten or 15 years from now, countries that produce in dirty ways are likely to face trade barriers. Cosbey and Wooders (2010:6) further highlight some of the technical tariff barriers that have been imposed by importers:

- British Standards Institute's PAS 2050, which offers the first carbon label standard;

- The World Business Council for Sustainable Development, which is piloting a product-based version of its GHG Protocol;

- France has introduced mandatory carbon for a range of products as of 2011; and

- The threat of highly contentious Border Carbon Adjustments (BCAs), as discussed earlier.

Indications from the latest reports of the IPCC (2014:10), referred to earlier, show that GHG emissions are on the rise, and developing and emerging economies will contribute a lot. For comparative purposes, the article also investigated the GEFs of Asian countries, as detailed in FIGURE 2. 


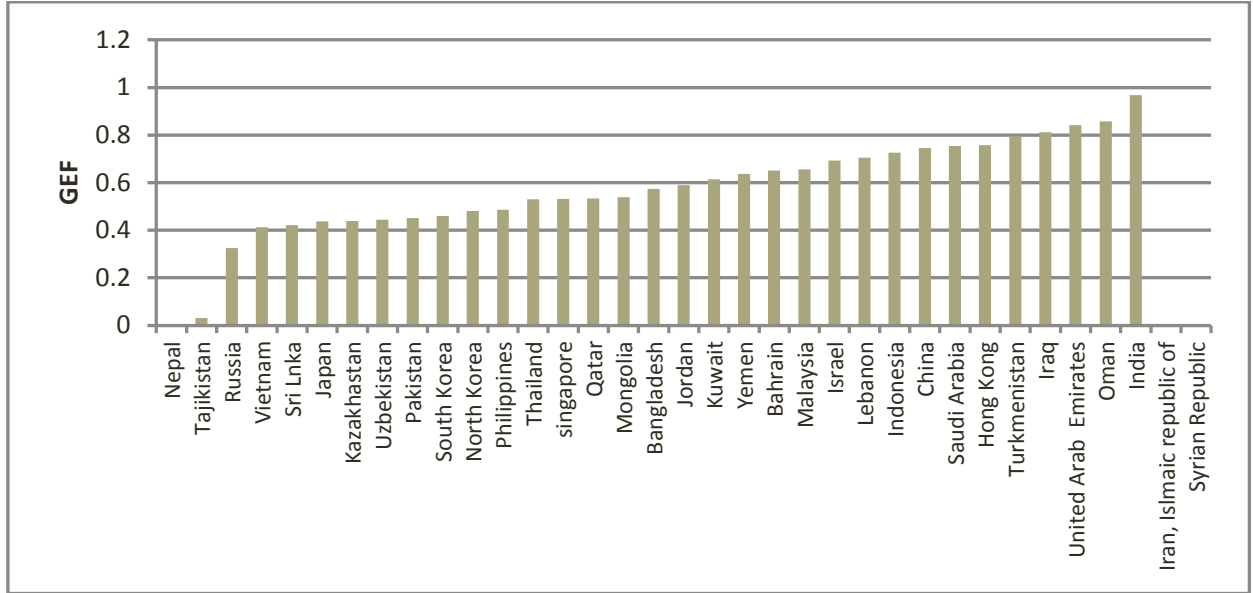

\section{FIGURE 2: Average GEFs of Asian countries (2008)}

Source: $\quad$ Constructed by the authors from data extracted from Econometrica (2011:4-7)

The results show that India, China and the United Arab Emirates (UAE) are among the countries in Asia that have high GEFs. As in the case of African countries with high GEFs, India's largest energy source of electricity is coal, followed by petroleum and traditional biomass and waste (EIA, 2014b:1). The same applies to China. FIGURE 3 shows electricity production in China, which is dominated by fossil fuels, which contribute more carbon emissions. China has abundant energy sources - for example, it has the third-largest coal reserves in the world. However, China also has massive hydroelectric resources.

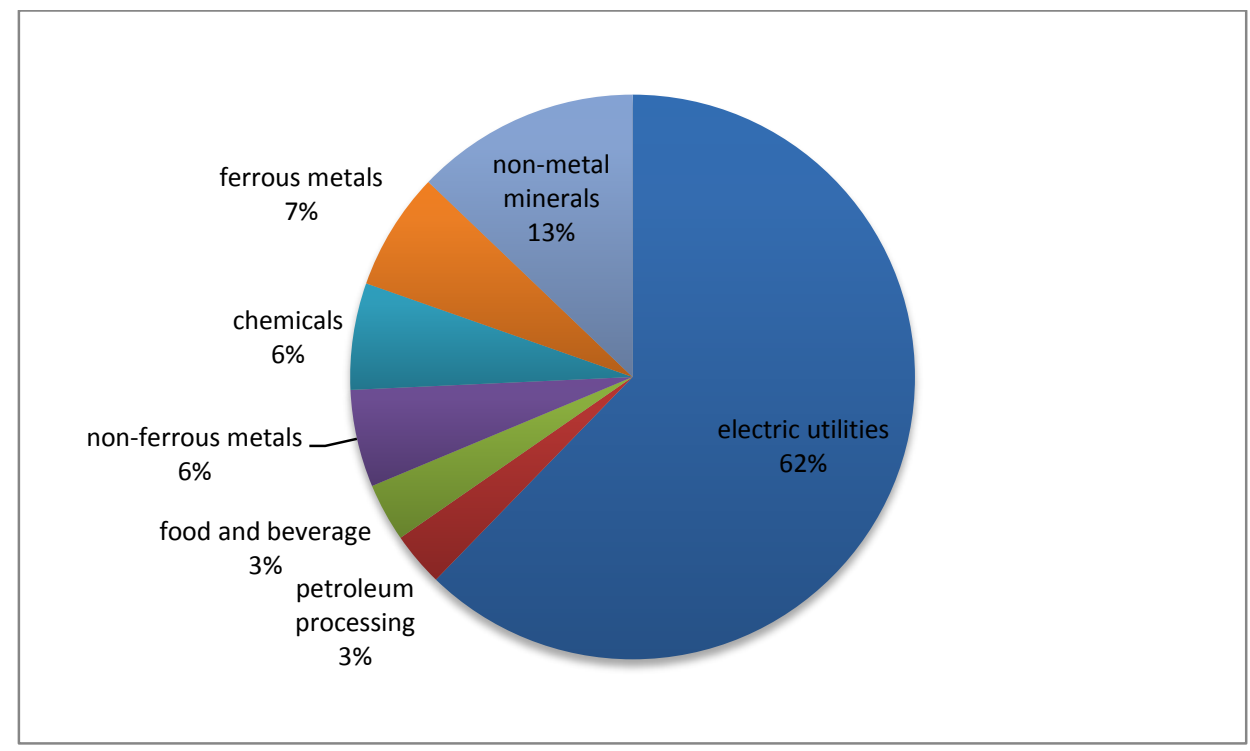

FIGURE 3: Sources of emissions in China (2006)

Source: Constructed by the authors (Yang, 2006:16) 
Statistics show that in 2002 about $40 \%$ of carbon dioxide, $55 \%$ of sulphur dioxide and $23 \%$ of particulate matter emissions were from the electricity industry (IEA, 2012: 2006). On average, generating $1000 \mathrm{kWh}$ electricity produced approximately 0.21 tonne of carbon dioxide, $4.6 \mathrm{~kg}$ of sulphur dioxide and $2 \mathrm{~kg}$ of particulate matter.

Econometrica (2011:10) maintains that composite electricity/heat factors vary by country. Variation is mainly due to the types of fossil fuel used to generate electricity and those used to produce heat. Some countries use nuclear mostly and hydro for electricity and maybe heat generation from fossil fuels or a waste combination. It is expected in this instance that the composite electricity-heat factors will be high. From the countries sampled, 21 out of 32 countries used are in the range between $0.51-1.01$ for their GEFs. The findings reveal a picture of not-soclean countries, as the GEFs are tending close to one. The overall picture when comparing the two continents is that Africa is relatively cleaner than Asia. Therefore, holding all other things constant (ceteris paribus), Europe and America, which are considered lucrative markets when choosing their trading partners and considering the carbon footprints of countries, African countries stand a better chance than their Asian counterparts. The picture is made clearer when the GEFs of the different continents and subcontinents are considered (FIGURE 4).

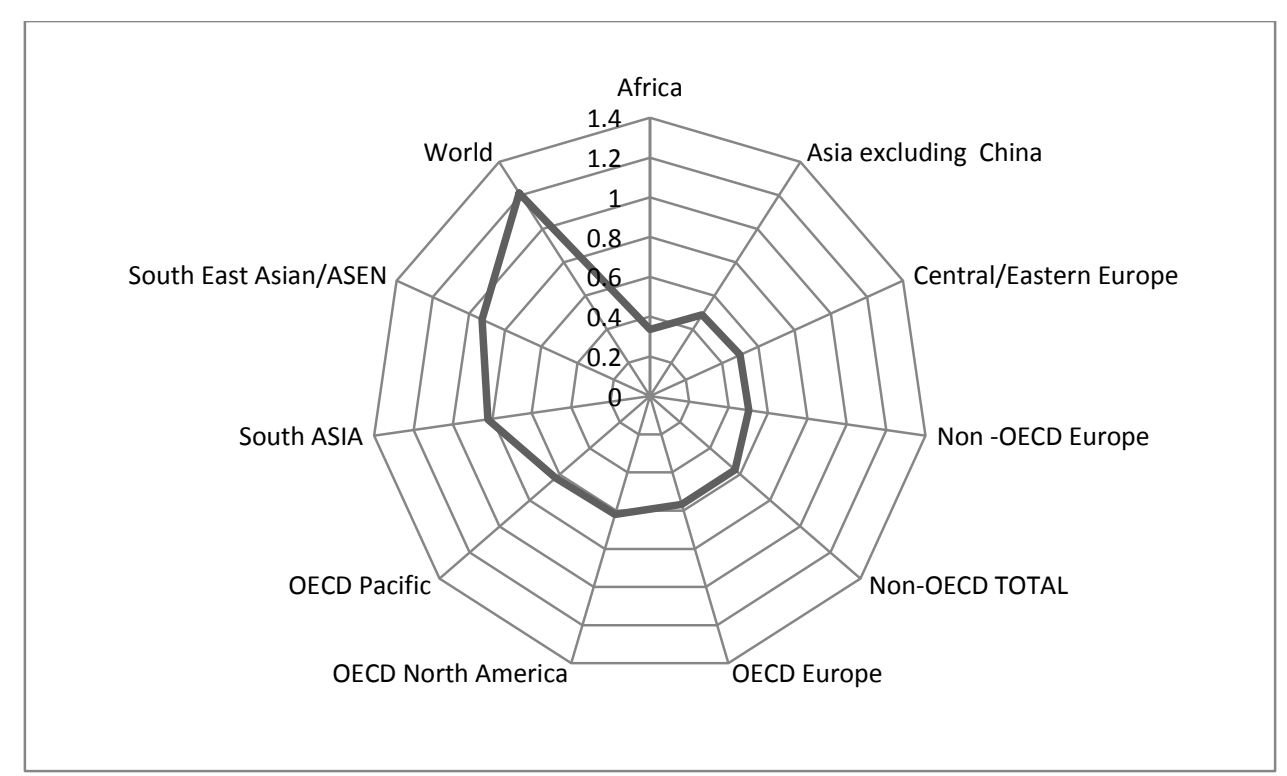

\section{FIGURE 4: GEFs of different continents and subcontinents (2008)}

\section{Source: $\quad$ Constructed by the Authors (Econometrica, 2011:4-7)}

South Asia has a high GEF (1.2138) compared to that of Africa, which is sitting at 0.6193. Also, Asia (excluding China) has a high GEF too. A glance at Central and Eastern Europe and the OECD and North America show that they have a lower GEF -0.822 and 0.4872 respectively. The OECD and non-0ECD sub-continents generally have lower GEFs when compared to Africa and Asia. Therefore, the issues of equidistance and accessibility will come into play when determining trading partners. The IPCC and UNFCCC reports indicate a reduction in emissions from developed countries. According to Peters et al. (2009:2) an increasing share of global emissions is from the production of internationally traded goods and services. The reason for this is current reporting practices, which allow some countries to increase their carbon footprints while reporting stabilised 
emissions. For instance, if one buys a sweater or a refrigerator, emissions from the production processes are assigned to the producing country, while these emissions remain invisible in the consuming country (Peter et al., 2009:2). Some countries can therefore increase their consumption (carbon footprint) while their officially reported emissions remain stable. In a nutshell, the lifecycle of a product is crucial, as it relates to the carbon footprint. The producing and consuming country would share the product's carbon footprint. The producing country's carbon footprint would be limited to the production method, while the consuming country would bear the usage and disposal carbon footprint. The production of traded goods and services, the authors report, accounted for $20 \%$ of global emissions in 1990 , and this increased to $26 \%$ in 2008 . The main findings of their study were that increased imports to rich countries have led to increased production and emissions in developing countries.

The accounting rules established under the UNFCCC require that countries report only territorial emissions. Hence, the developed nations do not need to report emissions caused by their consumption even if this contributes to global emissions. Global carbon accounting has received criticism from environmental campaigners who argue that global carbon accounting should be based on consumption rather than the production of goods and services (Carbon Accounts Biase).

To sum up, this article investigated GEFs for African and Asian countries, mainly because governments, in an attempt to achieve and retain global competitiveness in the international arena, have adopted policies to reduce GHG emissions. However, two major issues have arisen. First, carbon leakage can occur when mitigation policies are not the same across countries. Also, producers seek to locate in jurisdictions where production costs are least affected by emission constraints (Low, Marceau and Reinaud, 2011:1). Carbon leakage risks raise questions about the efficacy of climate change policies in a global sense. Secondly, it is precisely the cost-related consequences of differential mitigation policies that feed industry concerns about competitiveness. A strong link exists between environmental and competitiveness perspectives that fuses climate change and trade regimes in potentially problematic ways as governments contemplate trade actions to manage the environmental and/or competitiveness consequences of differential climate change policies (Low et al., 2011:1).

\section{CONCLUSIONS AND RECOMMENDATIONS}

This article focused on international trade and continent- and country-specific carbon footprints. The continent's and/or country's GEFs were applied as a unit of analysis linked to the carbon footprint. It turns out that GEFs constitute a useful but controversial tool to judge who (and who not) to trade within a context of climate change and green economy transition. Part of the challenge is that the GEFs may be unreliable and vary among countries. In Africa two countries, South Africa and Botswana, stand out in terms of their high GEFs, as these countries have green emission factors close to or above one. This picture is in contrast to Asian countries that do not have GEFs above one. A country with lower GEFs inherently has low carbon and cleaner products, an element that increases the chances of green investments and the production of green goods and services, thereby increasing its competitiveness. The article argues that, ceteris paribus, if GEFs are used to determine trading partners African products are on the whole likely to be more competitive in the international market than their Asian counterparts. This argument is based on a comparison of the averages of the two continents. There are other issues that can be used to determine trading partners, such as distance to the exporting destination, existence of bilateral and multilateral agreements, technical barriers such as tariffs and quotas and comparative 
advantage of a country to produce goods. The article proposes that GEFs can be used as a tool from a strategic approach perspective, which permits quick, informed decisions in choosing greener trading partners. A glance at some European and American countries revealed that they have lower GEFs than Africa and Asia. The suggested reason for this is that they import more from African and emerging economies. The article also noted that carbon accounting rules established under the UNFCCC require countries to report territorial emissions only. The Conventional carbon accounting systems do not mandate developed nations to report emissions caused by their consumption, even if this contributes to global emissions growth. The article therefore recommends that if countries want to remain competitive and not face stiffer trading barriers, new methods of producing electricity and heat must be adopted. There is a need to invest in efficient ways of generating electricity/heat. In addition, investments in renewable energy and energy-efficiency measures will not only help Africa and Asian countries meet their international carbon emission reduction target come the 2020 regime, but will also address trade issues and the need to achieve and remain competitive in the international market. Such investments will provide a win-win solution for policymakers if they wish to move Africa and Asia towards green growth without comprising economic development goals. Finally, the message to our politicians and technocrats remains: there is a need to green our national grids as appropriate.

\section{AREAS OF FURTHER RESEARCH}

The article recommends that specific studies that describe single and multi-region input and output models assessing the environmental-economic impact of internationally traded goods and services be done, especially for Africa and selected countries.

\section{LIMITATIONS OF THE STUDY}

The unavailability of data and updated information made it impossible for the researchers to look at countries' GEFs that combine emissions from fuel combustion. The GEFs from countries vary. Hence, the researchers had to settle for data from the International Energy Agency used by Econometrica, which is more accurate.

\section{LIST OF REFERENCES}

Blodgett, C. (2013). Grid Emission factors off-grid power generation. Kigali: Rwanda Environment Management Authority/UNDP.

Carbon Trust. (2007). Carbon Footprint Measurement Methodology, Version 1.1. 27 February 2007, the Carbon Trust, London, UK. Available: http://www.carbontrust.co.uk. (Accessed 17 March 2015).

Carbon Market Watch. (2014). Scrutinizing carbon markets and advocating fair, effective climate protection CDM UNFCCC. Brussels: Carbon Market Watch

Cosbey, A. (2008). Trade and climate change. Issues in perspectives. International Institute for Sustainable Development, UK. 
Cosbey, A. \& Wooders, P. (2010). The vulnerability of South African exports to climate change-related measures: Puantifying the impacts of BCAs and product standards, IISD-consultancy report to SARI. Pretoria: The South African Renewables Initiative (SARi)

Department of Economic and Social Affairs (DESA). (2013). World Economic and Social Survey. United Nations. New York. E/2013/50.Rev.1. ST/ESA/344. Available:

https://sustainabledevelopment.un.org/content/documents/2843WESS2013.pdf. (Accessed 16 March 2015).

De Mello, J. (2009). Trade in a 'Green Growth 'Development Strategy Global Scale Issues and Challenges. Working Paper series 48:211-222. Development policies. Washington DC: The World Bank.

De Mello, J. (2012). Trade in a 'Green Growth' Development Strategy: Global Scale Issues and Challenges. Washington DC: The World Bank.

Econometrica (2011). Technical Paper: Electricity-specific emission factors for grid electricity. Econometrica. Available: http://www.Emission factors.com.

Garside, B., MacGregor, J. \& Vorley, B. (2008). Review of food miles, carbon and African horticulture, COLEACP/PIP. Washington DC: COLEACP/PIP.

Grynberg, R. (2012). Coal exports and the diversification of Botswana's economy. Gaborone: Botswana Institute for Development Policy Analysis.

Hertwich, E.G \& Peters, G.P. (2009). The carbon Footprint of Nations: A Global, trade-Linked Analysis. Environ. Sci Technology, 43, pp. 6414-6420.

Hufbaure, C.G. \& Kim, J. (2009). The World Trade Organisation and climate change. Challenges and option. WP 09-0. Working Paper Series. Washington DC: Peterson Institute for International Economics.

International Energy Agency (IEA). (2011a). Key Energy Statistics 2011. Country specific indicators. International Energy Agency (IEA). (2011b). Statistics by country/region for electricity/heat (data for 2008). Available: http://www.iea.org/stats/prodresult.asp?PRODUCT=Electricity/Heat. (Accessed 25 February 2015).

International Energy Agency (IEA). (2013). Annual Report.

International Energy Agency (IEA). (2014a). Key World Energy Statistics. Available: http://www.eia.gov/countries/cab.cfm?fips=in. (Accessed 12 February 2015).

International Energy Agency (IEA). (2014b). The world energy investment outlook special report. IEA Inter-governmental Panel on Climate Change (IPCC). (2006). Guideline for National Inventories. IPCC. Available: https://www.ipcc.ch/pdf/activity/2006gls-brochure.pdf. (Accessed 27 February 2015).

IPCCAR5. (2014). Fifth Assessment Report, Synthesis Report, IPCC. Available:

http://www.ipcc.ch/report/ar5/. (Accessed 20 February 2015).

Low, P., Marceau, G. \& Reinaud, J (2011). The Interface between the Trade and Climate Change regimes: Scoping the issues. Staff Working Paper ERSD-2011-1 World Trade Organization Economic Research and Statistics Division Geneva.

Mac Consulting. (2013). South Africa's Grid Emission Factor. National Business Initiative. Available: http://www.nbi.org.za/Lists/Publications/Attachments/302/South\%20Africa's\%20Grid\%20Emission \%20Factor\%20Mar-13.pdf. (Accessed 03 March 2015). 
Muuru, J.G. (2009). Kenya's flying vegetables: Small farmers and the food miles debate. Africa Research Institute. Policy Voice series. London: Africa Research Institute.

Nhamo, G. (2014a). Policy coherence in Tackling Climate Change in Africa. Fact sheet 2. Heirich Boll Stiftung, Southern Africa. IPS. Available: http://www.ipsnews.net/documents/Policy-coherence-intackling-climate-change-in-Africa-fact-sheet.pdf. (Accessed 17 March 2015).

Nhamo, G. (2014b). From sustainable development through green growth to sustainable development plus. International Journal of African Renaissance Studies, 9(2), pp. 20-38. D0I: 10.1080/18186874.2014.987953.

Peters, G.P. (2008). From production-based to consumption-based national emissions inventories. Ecological Economics, 65(1), pp. 13-23.

Peters, G., Minx, J., Weber, C.L. \& Edenhofer, 0. (2011). Growth in emission transfers via International trade from 1990 to 2008. Proceedings of the National Academy of Sciences (PNAS), 108(21), pp. 8903-8908.

Resnick, D., Tarp, F. \& Thurlow, J. (2012). The Political Economy of Green-Growth: Illustrations from Southern Africa. UNU-WIDER Working Paper, No. 2012/11. Helsinki: United Nations University-World Institute for Development Economics Research.

Reuters. (2012). Planned power projects will beat Southern Africa's energy blues. Business Features. Available: http://www.iol.co.za/business/features/planned-power-projects-will-beat-southernafrica-s-energy-blues-1.1305571. (Accessed 20 March 2015).

Saunders, M., Lewis, M. \& Thornhill. A. (2007). Research Methods for Business students, $2^{\text {nd }}$ edition. Prentice Hall. Financial times.

South African Power Pool (SAPP) (2011). Capacity Development for community Project. Presentation at Second Workshop, 7-9 September 2011.

South Center Trade (SCT). (2009). Carbon Based Competitiveness and climate change. Perspectives of developing countries. Geneva: South Center.

Southern African Renewable Initiative (SARI). (2010). Unlocking South Africa Green Growth Potential. Pretoria: Department of Trade and Industries.

Spalding-Fecher, R. (2011). What is the carbon emission factor for the South African electricity grid? Poor management is consulting. Journal of Energy in Southern Africa, 22(4), pp. 8-14.

Stern, N. (2006). The Economics of Climate Change. The Stern Review. London: HM Treasury.

Timulak, L. (2009). Meta-analysis of qualitative studies. A tool for reviewing qualitative research findings in psychotherapy. Psychotherapy Research, 19 (4-5), pp. 591-600.

United Nations Environment Programme (UNEP). (2010). Assessing the Environmental Impacts of Consumption and Production: Priority Products and Materials. A Report of the Working Group on the Environmental Impacts of Products and Materials to the International Panel for Sustainable Resource Management. Paris: UNEP Division of Technology Industry and Economics

United Nations Environment Programme (UNEP). (2011). Towards a Green Economy: Pathways to Sustainable Development and Poverty Eradication. United Nations Environment Programme. Available:

http://www.unep.org/greeneconomy/greeneconomyreport/tabid/29846/default.aspxUNEP. (Accessed 25 February 2015). 
United Nations Environment Programme UNEP. (2013). Green Economy and Trade, Trends, challenges and opportunities. Available: http://www.unep/org/greeeconomy/greeneconomytrade. (Accessed 12 February 2015).

UNEP, ITC \& ICTSD. (2012). Trade and Environment Briefings: Trade and Green Economy; ICTSD Programme on Global Economic Policy and Institutions; Policy Brief No. 1. Geneva: International Centre for Trade and Sustainable Development.

United Nations Framework on Climate Change Convention (UNFCCC). (2007). Essential Background. Available: http://unfccc.int/essential_background/items/2877.php. (Accessed 20 February 2015).

Vickers, B. (2014). Trade and Climate Change: Constructing a multilateral Agenda for Africa. Pretoria: Department of Political Sciences University of South Africa, South Africa.

Weidman, T. \& Minx, J. (2008). A Definition of 'Carbon Footprint'. In: C.C. Pertsova, Ecological Economics Research Trends, Chapter 1, pp. 1-11, Nova Science Publishers, Hauppauge NY, USA. Available: https://www.novapublishers.com/catalog/product_info.php?products_id=5999. (Accessed 17 February 2015).

World Bank (WB). (2007). International Trade and Climate Change economic Legal and Institutional Perspectives. Environment and Development. Washington: The World Bank.

World Trade Organisation (WTO). (2011). Harnessing trade for sustainable development and a green economy. WTO Secretariat draft discussion. Available:

https://www.wto.org/english/res_e/publications_e/brochure_rio_20_e.pdf. (Accessed on 25 February 2015).

Yang, H. (2006). Overview of the Chinese Electricity and its current use, CWPE 0617 and EPRG 0517. Available: http://www.eprg.group.cam.ac.uk/wp-content/uploads/2014/01/eprg0517.pdf. (Accessed on 17 February 2015).

Zhang, Z. (2009). The US proposed Carbon tariffs, WTO scrutiny and China responses. Munich Personal REPEC chive. Available: http://mpra.ub.uni-muenchen.de/19063/1/MPRA_paper_19063.pdf. (Accessed on 12 February 2015). 